\title{
Dampak Perkembangan Pariwisata Pantai Tambakrejo Terhadap Ekonomi Masyarakat Desa Tambakrejo Kabupaten Blitar
}

Gendis Wedar Nugraheni a, 1, Ida Bagus Suryawan a, 2

${ }^{1}$ wedargendis@gmail.com, 2 idabagussuryawan@unud.ac.id

a Program Studi S1 Destinasi Pariwisata, Fakultas Pariwisata,Universitas Udayana, Jl. Dr. R. Goris, Denpasar, Bali 80232 Indonesia

\begin{abstract}
Tambakrejo Beach is located in Tambakrejo Village, Wonotirto district, South of Blitar City. Communities around the Tambakrejo Beach initially work as fishermen, traders, farmers, and to meet the daily needs in getting from fishing. However today many people are turning their professions into traders. The tourism development of Tambakrejo beach resulted in changes of community activities.

The method used to collect the data in this study are observation, interview, questionnaires, and literature study and the methods used to analyze the data is comparative descriptive analysis method.

The results of this study related to the tourism development that tourists visits increases every year. The interaction of tourists with the community is also high, the number of tourist facilities increased, the attractions are two activities such as boating and riding ATV and watching Islamic local culture Larung Sesaji in the beach, and promotion is done with social media and cooperation between magazine and television to review Tambakrejo in their program. The results of the tourism development toward communities economy is community income increased and employment opportunities associated with the movement of livelihoods as a trader.
\end{abstract}

Keywords : The Impact, Tourism Development, Community Economy, Tambakrejo

\section{PENDAHULUAN}

Jawa Timur merupakan salah satu provinsi yang ada di Pulau Jawa, yang memiliki 29 Kabupaten dan 9 Kota. Salah satu Kabupaten di Jawa Timur adalah Kabupaten Blitar. Blitar memiliki daya tarik wisata alam, budaya, dan buatan. Daya tarik wisata alam yang sedang dikembangkan yaitu Pantai Tambakrejo. Pantai Tambakrejo berada di Kabupaten Blitar yang letaknya di sebuah teluk dengan panjang sekitar $10 \mathrm{~km}$. Sebagian besar masyarakat disekitar Pantai Tambakrejo bermata pencaharian sebagai nelayan, pedagang dan petani. Untuk memenuhi kebutuhan sehari-hari masyarakat menggunakan penghasilan dari menangkap ikan. Seiring berjalannya waktu Pantai Tambakrejo mulai ramai dikunjungi wisatawan.

Pariwisata membawa perubahan pada perekonomian lokal. Pariwisata merupakan multisektoral dan saling mempengaruhi dengan sektor-sektornya yang bersinggungan sehingga muncul keadaan dimana pariwisata akan meningkatkan pertumbuhan dan perkembangan serta menginjeksi keadaan ekonomi lokal. Pariwisata dianggap sebagai penggerak perekonomian atau penghasil devisa untuk pembangunan ekonomi disuatu negara, begitu pula dengan Indonesia. Pada kenyataanya, pariwisata mempunyai spektrum fundamental pembangunan yang lebih luas untuk suatu negara (Utama, 2015). Pengerakan ekonomi tersebut juga langsung dirasakan oleh masyarakat lokal yang mampu memanfaatkan momentum daerahnya menjadi daya tarik wisata. Terbukanya peluang ekonomi yang menjanjikan dari sektor pariwisata dimanfaatkan secara kreatif oleh masyarakat sekitar.

Masyarakat sekitar Tambakrejo memanfaatkan peluang dari perkembangan pariwisata di Pantai Tambakrejo. Mereka membuka usaha, seperti berprofesi menjadi pedagang makanan dan minuman di pinggir pantai, serta menjual ikan segar. Tentunya perkembangan Pantai Tambakrejo dapat diketahui dengan melihat trend pertumbuhan wisatawan dan kenaikan jumlah akomodasi untuk kegiatan pariwisata. Perkembangan Pantai Tambakrejo dapat diidentifikasi melalui perkembangan dan peningkatan jumlah wisatawan yang berkunjung ke Pantai Tambakrejo. Peneliti merasa penting untuk melihat bagaimanakah dampak yang timbul dari adanya perkembangan pariwisata di Pantai Tambakrejo terhadap kondisi terkini dan juga terhadap ekonomi masyarakat sekitar Desa Tambakrejo.

\section{TINJAUAN PUSTAKA}

Penelitian ini menggunakan beberapa konsep yang dapat dijadikan landasan analisis data yang didapat di lapangan, adapun beberapa konsep tersebut yaitu: 
1. Konsep dampak pariwisata menurut Faizun (2009) adalah perubahanperubahan yang terjadi terhadap masyarakat sebagai komponen dalam lingkungan hidup sebelum ada kegiatan pariwisata dan setelah ada kegiatan pariwisata.

2. Konsep dampak sosial ekonomi menurut Cohen (1984) dalam Pitana dan Gayatri (2005) dapat dikategorikan menjadi delapan kelompok besar yaitu : Dampak terhadap penerimaan devisa negara, pendapatan masyarakat, kesempatan kerja, harga-harga, distribusi manfaat/keuntungan, kepemilikan dan kontrol, pembangunan pada umumnya dan dampak terhadap pendapatan pemerintah.

3. Teori siklus hidup destinasi menurut Butler (1980) dalam (Richardson dan Fluker, 2004) yang membagi siklus hidup desitinasi sebagai berikut : eksplorasi (exploration), keterlibatan (involvement), pembangunan (development), konsolidasi (consolidation), stagnasi (stagnation), penurunan (decline), dan peremajaan (rejuvination)

\section{METODE}

Penelitian ini dilakukan di Pantai Tambakrejo yang lokasinya di Desa Tambakrejo, Kecamatan Wonotirto, Kabupaten Blitar. Adapun ruang lingkup penelitian yang digunakan yaitu :

1. Perkembangan pariwisata di daya tarik wisata Pantai Tambakrejo, perkembangan pariwisata yang dilihat mencakup;
a) Tingkat jumlah kunjungan wisatawan sebelum dan sesudah adanya pariwisata,
b) Interaksi wisatawan dengan masyarakat,
c) Fasilitas,
d) Atraksi,
e) Promosi.

2. Dampak ekonomi masyarakat Desa Tambakrejo yang mencakup;

a) Pendapatan masyarakat,

b) Kesempatan kerja.

Jenis dan sumber data dalam penelitian

ini menggunakan jenis dan sumber data menurut (Kusmayadi dan Sugiarto, 2000). Jenis data kualitatif, seperti yang diperoleh berdasarkan berbagai informasi dari informan terkait dengan keberadaan daya tarik wisata Pantai Tambakrejo, perkembangan pariwisata yang berkaitan dengan interaksi masyarakat dan wisatawan, fasilitas, atraksi, serta promosi. Dan data kuantitif yang dimaksud berupa data jumlah kunjungan wisatawan dan dampak ekonomi masyarakat di Pantai Tambakrejo. Sumber data primer dalam penelitian ini didapat secara langsung dari informan baik lisan maupun tulisan tentang gambaran umum Pantai Tambakrejo serta dampak yang ditimbulkan dari adanya perkembangan pariwisata di Pantai Tambakrejo dan sumber data sekundernya dalam penelitian ini terkait dengan dokumen dan arsip mengenai data jumlah penduduk Desa Tambakrejo.

Penelitian ini menggunakan teknik pengumpulan data yaitu: observasi, wawancara, kuesioner, dan studi kepustakaan (Sugiyono, 2014). Untuk menentukan informan menggunakan teknik purposive sampling, yaitu peneliti mengetahui orang-orang yang akan dijadikan informan. Informan yang dimaksud yaitu mereka yang mengetahui tentang aspek data yang dibutuhkan dalam permasalahan penelitian (Bungin, 2007). Teknik analisis data dalam penelitian ini menggunakan teknik analisis data deskriptif kualitatif yaitu mereduksi data, penyajian data, dan penarikan kesimpulan atau verifikasi (Sugiyono, 2014).

Perkembangan pariwisata di

Tambakrejo akan dimulai dengan pengumpulan data yang masih umum, kemudian data yang ditemukan tersebut dicari hubungan antar kategorinya terkait perkembangan pariwisata dan dampak ekonominya, kemudian disajikan dalam bentuk uraian deskriptif. Penarikan simpulan digunakan pada hasil penelitian yang sudah sesuai dengan tema serta permasalahan penelitian.

\section{HASIL DAN PEMBAHASAN}

Daya Tarik Wisata Pantai Tambakrejo terletak di Desa Tambakrejo, Kecamatan Wonotirto, Kabupaten Blitar. Pantai Tambakrejo ditemukan pada tahun 1970 oleh karena itu kealamian yang dimiliki masih terjaga. Pantai Tambakrejo dikelola sejak ditetapkannya Peraturan Daerah Kabupaten Blitar Nomor 19 Tahun 2000 tentang Retribusi 
Perizinan Usaha dan Retribusi Jasa Rekreasi, Hiburan dan Tempat rekreasi, olahraga oleh PEMDA (Dinas Pariwisata Kebudayaan Pemuda dan Olahraga).

Letak Pantai Tambakrejo secara geografis berada di $30 \mathrm{~km}$ di selatan kota Blitar dan bisa ditempuh dengan waktu 2,5 jam dari kota Kediri. Aksessibilitas menuju kawasan Pantai Tambakrejo masih sangat kurang, hal tersebut disebabkan oleh lebar jalan yang masih sempit dan curam untuk dilewati. Hal ini kurang nyaman untuk dilewati oleh bus besar yang mengangkut wisatawan yang datang ke pantai Tambakrejo.

Lokasi Daya Tarik Wisata Pantai Tambakrejo ini dekat dengan Pantai Pangi, Pantai Pasir Putih (Gondo Mayit), dan Monumen Trisula. Pantai Tambakrejo memiliki pemandangan yang indah, pantai yang bersih, dengan air laut yang biru, dan pasir putih yang terbentang menjadi sebuah teluk dengan panjang sekitar $10 \mathrm{~km}$. Pada kawasan Pantai Tambakrejo terdapat kampung nelayan dengan perahu-perahunya. Kegiatan yang dilakukan di Pantai Tambakrejo adalah melihat keindahan bentang alam Pantai Tambakrejo yang menarik bagi wisatawan untuk berkunjung dengan ombak yang tidak terlalu besar. Wisatawan yang berkunjung dapat berjemur, mandi di pantai, berkeliling disekitar Pantai Tambakrejo dengan perahu nelayan, dan wisatawan juga dapat menikmati wisata kuliner khas makanan laut dan minuman yang tersedia di warungwarung pinggir Pantai Tambakrejo.

Bangunan warung yang berada di pinggir Pantai Tambakrejo bersifat semi permanen yang dilihat dari atapnya yang menggunakan asbes. Sedangkan tempat duduk dan meja berbahan dari kayu dan plastik.

Secara demografis Desa Tambakrejo memiliki luas wilayah sebesar $4.89 \mathrm{Km}^{2}$, untuk presentase luas wilayah terhadap kecamatan sebesar 2.97\%. Jumlah penduduk di Desa Tambakrejo sebanyak 5.108 orang dan kepadatan di Desa Tambakrejo sebanyak 1.045 jiwa/Km². Kegiatan ekonomi yang ada di Pantai Tambakrejo yaitu adanya kegiatan jual beli yang berupa pakaian, ikan bakar, ikan segar dan berbagai macam minuman.

1. Perkembangan Pariwisata di Pantai Tambakrejo.

Perkembangan pariwisata di Pantai Tambakrejo yang dipengaruhi oleh fasilitas dan amenitas, seperti pembangunan jalan menuju pantai Tambakrejo, adanya TPI (Tempat Pelelangan Ikan). Perkembangan yang mulai terjadi pada tahun 2012 namun kunjungan wisatawan mulai meningkat secara signifikan terjadi pada tahun 20152016. Perkembangan pada Pantai Tambakrejo dilihat dari jumlah kunjungan wisatawan, interaksi wisatawan dengan masyarakat lokal, fasilitas pendukung kegiatan wisata, atraksi, dan promosi.

a. Jumlah Kunjungan Wisatawan

Jumlah kunjungan wisatawan

yang digunakan untuk melihat perkembangan pariwisata di Pantai Tambakrejo dimulai tahun 2011- 2016. Pada Tahun 2011 jumlah kunjungan wisatawan mencapai 1.898 orang dan meningkat pada tahun 2012 mencapai 5.738 orang dan terus mengalami peningkatan hingga pada tahun 2016 menjadi 116.702 orang (hasil penelitian, 2017).

b. Interaksi Wisatawan dengan Masyarakat Lokal

Interaksi masyarakat dan wisatawan menjadi faktor terpenting bagi munculnya keharmonisan keberlangsungan pariwisata. Pada sekitar tahun 2012 jumlah kunjungan wisatawan yang berkunjung ke Pantai Tambakrejo masih sangat sedikit, hal ini dikarenakan daya tarik wisata Pantai Tambakrejo belum banyak dikenal oleh masyarakat luar. Masyarakat lokal masih awam terhadap adanya pariwisata dan dengan seiring berjalannya waktu dan perkembangannya teknologi dapat menyebabkan daya tarik wisata Pantai Tambakrejo mulai dikenal masyarakat luar maupun wisatawan, perlahan jumlah kunjungan wisatawan mulai meningkat setiap tahunnya, selain itu respon dari masyarakat lokal sendiri sangat baik dan ramah menerima kedatangan wisatawan yang berkunjung ke Pantai Tambakrejo.

Dengan keramahan masyarakat lokal kepada wisatawan, wisatawan menjadi lebih nyaman berada di Pantai Tambakrejo. 
c. Fasilitas di Pantai Tambakrejo

Fasilitas pariwisata di Pantai Tambakrejo dapat dilihat dari warung, toilet, area parkir, penginapan, musola, perahu, dan toko souvenir. Jumlah dari fasilitas-fasilitas tersebut bertambah seiring dengan masuknya perkembangan pariwisata.

Fasilitas pendukung kegiatan wisata sebelum berkembangnya Pantai Tambakrejo sebesar 35 unit pada tahun 2011. Terdiri dari 19 warung, 5 toilet, 5 area parkir, 1 penginapan, 1 musola, 2 perahu dan 2 toko souvenir. Sedangkan setelah Pantai Tambakrejo berkembang fasilitas pendukung mengalami peningkatan sebesar 106 unit pada tahun 2016 yang terdiri dari 64 warung, 16 toilet, 9 area parkir, 1 penginapan, 1 musola, 4 perahu, 11 toko souvenir.

d. Atraksi di Pantai Tambakrejo

Sebelum adanya kegiatan pariwisata Tambakrejo hanyalah sebuah pantai biasa. Bahkan cenderung berbahaya dengan ombaknya yang besar. Perkembangan pariwisata telah membuat banyak perubahan terhadap Pantai Tambakrejo. Perubahan tersebut seperti munculnya aktifitas baru yang dapat dilakukan oleh wisatawan selama berkunjung contohnya adalah perahu yang dapat disewakan bagi wisatawan yang ingin merasakan sensasi menaiki perahu nelayan dan juga kegiatan mengendarai ATV (All Terain Vehicle) bagi wisatawan yang lebih suka bermain di darat.

Kegiatan lain yang terdapat di Pantai Tambakrejo yaitu Tempat Pelelangan Ikan (TPI) dan Ritual Larung Sesaji. Tempat Pelelangan Ikan (TPI) memiliki luas lahan sekitar 4,9 hektare. Lokasi ini menjadi tempat untuk berlabuh atau bersandarnya kapalkapal besar maupun kapal-kapal kecil. Di tempat ini, wisatawan yang berkunjung bisa langsung menikmati bagaimana proses para nelayan yang sedang menangkap ikan, selain itu wisatawan juga dapat menikmati wisata kuliner ikan laut yang menjadi andalan Pantai Tambakrejo Kabupaten Blitar.
Terdapat juga Ritual Budaya Larung Sesaji dilakukan setiap tahun baru Islam (Muharam) atau pada Bulan Suro. Dengan tujuan melestarikan budaya adat jawa, yang digunakan untuk wujud rasa syukur para nelayan dengan Tuhan Yang Maha Esa dengan melimpahnya rezeki, hasil tangkapan ikan yang didapatkan dan terhindarnya dari segala macam bahaya. Tidak ada data yang jelas kapan dimulainya ritual ini, namun diperkirakan ritual ini telah lama ada. Ritual Budaya Larung Sesaji ini juga dapat menarik wisatawan untuk berkunjung ke Pantai Tambakrejo, untuk menyaksikan adat dan budaya yang masih kental.

e. Promosi

Promosi sangat penting bagi suatu daya tarik wisata yang baru merintis karena dengan adanya promosi wisatawan dapat mengetahui potensi yang ada di Blitar. Hal ini juga terjadi pada Pantai Tambakrejo.

Sebelum berkembangnya pariwisata. Tidak ada wisatawan dari luar yang mengenal Pantai Tambakrejo di Blitar. Wisatawan hanya mengetahui Makam Bung Karno sebagai daya tarik yang harus dikunjungi jika berada di Blitar. Seiring dengan perkembangan waktu promosi semakin gencar dilakukan dengan tujuan mengembangkan pariwisata di Pantai Tambakrejo yaitu dengan cara mempromosikan melalui media sosial dan kerja sama. Media sosial menggunakan media promosi yang sangat dekat dan sering dipakai oleh masyarakat Indonesia dan dunia yaitu dalam bentuk instagram dan twitter dengan kata kunci share Blitar. Sedangkan kerjasamanya dengan majalah maupun stasiun televisi seperti Inflifht Citilink, Liputan TVRI, dan Metro TV.

Berdasarkan Teori Area Life Cycle milik Butler perkembangan pariwisata di Pantai Tambakrejo berada pada tahap keterlibatan (involvement) yang ditandai seperti tingkat kunjungan wisatawan mulai meningkat setiap tahunnya, mulai banyaknya interaksi 
wisatawan dengan masyarakat, fasilitas pariwisata mulai bertambah karena adanya keterlibatan masyarakat dalam membangun fasilitas tersebut, terdapat dua kegiatan yang dapat dinikmati pada atraksi di Pantai Tambakrejo, dan promosi sudah mulai dilakukan baik menggunakan media sosial serta kerja sama dengan pihak lain.

2. Dampak Terhadap Ekonomi Masyarakat

a. Pendapatan Masyarakat

Pendapatan masyarakat sebelum berkembangnya pariwisata di Pantai Tambakrejo berdasarkan hasil penyebaran kuesioner kepada 30 orang masyarakat yaitu ; 13 responden <Rp.500.000, 21 responden Rp.500.000-Rp.1.000.000, 6 responden Rp.1.000.000-Rp.2.000.000 lalu >Rp.2.000.000 sebesar 0 responden. Sedangkan pendapatan masyarakat sesudah berkembangnya Pantai Tambakrejo yang penghasilannya $<$ Rp.500.000 tidak ada, 13 responden Rp.500.000-Rp.1.000.000, 17 responden Rp.1.000.000-Rp.2.000.000, 10 responden $>$ Rp.2.000.000.

Dampak perkembangan pariwisata terhadap pendapatan masyarakat di Pantai Tambakrejo yaitu mengalami kenaikan. Hal ini dapat dilihat bahwa sebelumnya masih ada masyarakat yang berpenghasilan $<$ Rp.500.000, namun saat ini sudah tidak ada masyarakat yang berpenghasilan <Rp.500.000. Dan masyarakat yang dulunya berpenghasilan $>$ Rp.2.000.000 tidak ada sedangkan sekarang dari 30 responden terdapat 10 orang responden yang berpenghasilan $>$ Rp.2.000.000 (hasil penelitian, 2017).

b. Kesempatan Kerja

Mata pencaharian sebelum berkembangnya Pantai Tambakrejo dari 30 orang responden yang diberikan kuesioner terdiri dari 12 responden sebagai nelayan, 14 responden petani, 7 responden pedagang, 7 responden lainnya sebagai ibu rumah tangga. Sedangkan mata pencaharian masyarakat sesudah berkembangnya Pantai Tambakrejo yaitu 10 responden sebagai nelayan, 2 responden petani, 28 responden pedagang dan untuk mata pencaharian lainnya tidak ada.
Dampak perkembangan pariwisata terhadap kesempatan kerja masyarakat di Pantai Tambakrejo yaitu yang awalnya masyarakat banyak bermata pencaharian sebagai petani namun sekarang banyak masyarakat yang beralih profesi sebagai pedagang. Meskipun masih banyak masyarakat yang bermata pencaharian seperti sebelum adanya perkembangan pariwisata di Pantai Tambakrejo.

\section{SIMPULAN DAN SARAN}

\section{Simpulan}

Simpulan dari penelitian ini bahwa Pantai Tambakrejo terletak di Desa Tambakrejo Kabupaten Blitar. Jarak dari Kota Blitar ke Pantai Tambakrejo $30 \mathrm{~km}$ dan bisa ditempuh dengan waktu 2,5 jam dari kota Kediri. Perkembangan pariwisata di daya tarik wisata Pantai Tambakrejo, yaitu jumlah kunjungan wisatawan di Pantai Tambakrejo setiap tahunnya meningkat. Kunjungan paling tinggi sebesar 116. 702 wisatawan, dan kunjungan paling rendah sebesar 1898 wisatawan. Seiring jumlah kunjungan wisatawan yang mulai meningkat setiap tahunnya maka interaksi wisatawan juga semakin tinggi. Selain itu respon dari masyarakat lokal sendiri sangat baik dan ramah menerima kedatangan wisatawan. Fasilitas yang berada di Pantai Tambakrejo yaitu toilet, musola, penginapan, warung, area parkir, perahu, toko souvenir. Atraksi yang berada di Pantai Tambakrejo adalah pantai, dengan kegiatannya yaitu Tempat Pelelangan Ikan (TPI) dan Ritual Larung Sesaji. Promosi yang dilakukan di Pantai Tambakrejo menggunakan media sosial dan kerja sama dengan pihak lain. Berdasarkan Teori Area Life Cycle perkembangan pariwisata di Pantai Tambakrejo berada di tahap keterlibatan (involement).

Dampak terhadap ekonomi masyarakat di daya tarik wisata Pantai Tambakrejo terkait dengan pendapatan masyarakat dampaknya yaitu pendapatan masyarakat menjadi meningkat. Sedangkan terkait dengan kesempatan kerja, banyak masyarakat yang beralih profesi menjadi pedagang. 


\section{Saran}

Pemerintah diharapkan untuk lebih memperhatikan akses khususnya jalan menuju Pantai Tambakrejo, seperti perbaikan jalan yang rusak dan memperlebar jalan. Pemerintah diharapkan memperhatikan warung yang berada di pinggir Pantai Tambakrejo agar ditata lebih baik dan rapi.

Masyarakat disekitar Pantai Tambakrejo dapat membuat paguyuban atau kelompok. Paguyuban tersebut mengundang orang yang ahli dalam wirausaha, untuk memberikan sosialisasi kepada anggota paguyuban. Sehingga masyarakat sekitar Pantai Tambakrejo dapat berkreasi dengan menggunakan bahan ikan, seperti ikan yang diolah menjadi abon atau keripik ikan dan batok kelapa yang dijadikan sebagai kerajinan, seperti tas dan dompet.

Masyarakat diharapkan menjaga kebersihan Pantai Tambakrejo dan ramah terhadap pengunjung. Masyarakat lebih terbuka terhadap aturan yang dibuat oleh pemerintah daerah, terkait dengan kawasan Pantai Tambakrejo. Pantai Tambakrejo saat ini memiliki warung yang tidak tertata dengan rapi. Sehingga peneliti selanjutnya dapat meneliti tentang kebijakan pembangunan fasilitas-fasilitas yang ada di Pantai Tambakrejo.

Masyarakat disekitar Pantai Tambakrejo dapat membuat paguyuban atau kelompok. Paguyuban tersebut mengundang orang yang ahli dalam wirausaha, untuk memberikan sosialisasi kepada anggota paguyuban. Sehingga masyarakat sekitar Pantai Tambakrejo dapat berkreasi dengan menggunakan bahan ikan, seperti ikan yang diolah menjadi abon atau keripik ikan dan batok kelapa yang dijadikan sebagai kerajinan, seperti tas dan dompet.

$$
\text { Masyarakat diharapkan menjaga }
$$

kebersihan Pantai Tambakrejo dan ramah terhadap pengunjung. Masyarakat lebih terbuka terhadap aturan yang dibuat oleh pemerintah daerah, terkait dengan kawasan Pantai Tambakrejo. Pantai Tambakrejo saat ini memiliki warung yang tidak tertata dengan rapi. Sehingga peneliti selanjutnya dapat meneliti tentang kebijakan pembangunan fasilitas-fasilitas yang ada di Pantai Tambakrejo.

\section{DAFTAR PUSTAKA}

Bungin, Burhan H.M. 2007. Penelitian Kualitatif Komunikasi, Ekonomi, Kebijakan Publik, dan Ilmu Sosial. Jakarta : Kencana Prenama Media Group

Faizun, Moh. 2009. Dampak Pariwisata Terhadap Lingkungan. Jakarta : Erlangga.

Kusmayadi dan Sugiarto, Endar. 2000. Metode Penelitian dalam bidang Kepariwisataan. Jakarta:Gramedia Pustaka Utama

Pitana, I Gde dan Gayatri, P.2005.Sosiologi Pariwisata. Yogyakarta: Penerbit Andi

Richardson, Jhon I and Fluker. 2004. Understanding and Managing Tourism. Pearson Education Australia.

Sugiyono. 2014. Metode Penelitian Kuantitatif, Kualitatif dan $R \& D$. Bandung:Alfabeta

Utama, I Gst. Bagus Rai. 2015. Strategi Menuju Pariwisata

Bali yang Berkualitas. Jurnal Kajian Bali. 